\title{
HUBUNGAN PEMBENTUKAN KARAKTER DI KELUARGA DAN \\ DI SEKOLAH DENGAN PRESTASI BELAJAR ANAK DI \\ SEKOLAH DASAR BERBASIS AGAMA ISLAM DAN \\ BUDHA SEKOTA MADYA MEDAN
}

\author{
OLEH: \\ SUTRISKA SIANTURI \\ (PGSD FKIP UNIVERSITAS KATOLIK SANTO THOMAS)
}

\begin{abstract}
This research is aimed to know the correlation of the Character Building in Family and School to the Child's Learning Achievement at the Elementary School Based on the Muslims and Budha Religion in the City of Medan. This is a correlation research using quantitative approach. The population used in this research are grades four and five pupils of the elementary school based on Muslim and Budha religion in the city of Medan with the total of six hundred pupils. The sampling quota was used in sampling process. Datas in this research were obtained by using character building questionnaire in families and school. The analysis technique in this research is using Statistic Program For Social Science (SPSS). The calculation result showed that the answer of the respondents about the five aspects; religion, honesty, dicipline, social solidarity and responsibility proved that the character building of pupils in the family and school correlates to pupils learning achievement.
\end{abstract}

Key words : character building, learning achievement

\section{PENDAHULUAN}

\section{Latar Belakang}

Seorang siswa SMA di SampangMaduramenganiaya gurunya sampai meninggal dunia hanya karena guru tersebut menegur siswa ketika jam pelajaran berlangsung. Ketika proses pembelajaran berlangsung, siswa tersebut tidak memperhatikan pelajaran malah asik mengganggu temannya dan mencoret-coret lukisan temannya. Ketika ditegur siswa tidak mau mendengarkan bahkan semakin menjadi-jadi akhirnya guru tersebut mencoret bagian pipi siswa itu dengan cat lukis (Kompas,2018).Tahun 2016 silam juga beredar video seorang siswa SD yang menantang seorang guru ketika guru tersebut memberikan nasehat dan peringatan. Siswa tersebut menatap tajam sambil membusungkan dadanya kepada si guru. Anak tersebut juga mengolok-olok gurunya dengan menyebut gurunya monyet (Tribun, 2016). Di Pontianak juga terjadi kekerasan fisik yang dilakukan oleh seorang siswa SMP terhadap gurunya. Kejadian tersebut bermula ketika proses belajar mengajar sedang berlangsung. Saat pembelajaran 
berlangsung, siswa tersebut asik menggunakan ponselnya dan tidak memperhatikan pelajaran. Lalu guru tersebut menegur siswa yang sedang asik bermain ponsel, mungkin karena kesal dan tidak terima, siswa tersebut memukul gurunya dengan menggunakan kursi plastik dan melemparkan ponselnya tepat mengenai leher si guru (Kompas, 2018). Itu merupakan sebagian dari beberapa kasus kekerasan yang dilakukan oleh siswa zaman sekarang terhadap gurunya.

Menurut Sudaryanti (2012:12), pembentukan karakter pribadi anak (character building) sebaiknya dimulai dalam keluarga karena anak mulai berinteraksi pertama kali di dalam lingkungan keluarga. Pendidikan karakter sebaiknya diterapkan sejak anak usia dini karena pada usia dini terbukti sangat menentukan kemampuan anak dalam mengembangkan potensinya. Sedangkan sekolah merupakan satu lembaga yang bertanggung jawab terhadap pembentukan karakter, karena kontribusi dan peran guru sangat penting.Pembentukan karakter anak dapat mengikuti suatu pola tertentu, yaitu suatu perilaku yang teratur, disiplin, artinya berbagai jenis dan pola perilaku tersebut dapat di kembangkan melalui penjadwalan secara terus menerus hingga perilaku yang diharapkan melekat pada anak secara kuat dan menjadi bagian dari perilaku positif yang dimilikinya.

Menurut Sudaryanti (2012:13), prestasi belajar yang diperoleh anak menunjukkan tingkat kompetensi yang dikuasai selama proses belajar. Pencapaian prestasi belajar anak tidak hanya didukung oleh kompetensi peserta didik saja, melainkan oleh guru. Setiap guru dan anak menginginkan tercapainya sebuah prestasi belajar yang tinggi, karena prestasi belajar yang tinggi merupakan salah satu indikator keberhasilan proses belajar. Jika anak sudah terbiasa untuk bertanggungjawab terhadap dirinya dan tugas-tugasnya di dalam keluarga, maka anak juga akan terbiasa untuk bertanggungjawab terhadap tugas yang diberikan oleh guru. Banyak anak yang memiliki kecerdasan di atas rata-rata tetapi jika anak kurang mendapat perhatian dan dukungan dari keluarga maka sering kali anak tidak mampu mengembangkan potensi yang dimilkinya.

Fathurrohman(Sianipar dan Nainggolan, 2014:2) menemukan bahwa, "muatan pendidikan nilai mulai pudar dalam proses pendidikan. Pendidikan hanya sebatas transfer of knowledge (memindahkan pengetahuan) sehingga yang terjadi adalah orang bersekolah hanya sebatas mengejar pengetahuan intelektual lewat angka-angka saja'. Para siswa tidak dibekali dengan nilai-nilai yang penting untuk masa depan mereka. 
Akibatnya adalah munculnya generasi instan yang ingin segala sesuatu diperoleh dengan serba cepat dan mudah.Mereka tidak lagi memiliki daya juang untuk mendapatkan sesuatu yang menjadi cita-cita atau harapan pribadi maupun bersama.Banyak nilai-nilai yang perlu ditanamkan dalam diri anak didik.Fathurrohman selanjutnya menambahkan bahwa, "nilai-nilai yang perlu ditanamkan dalam diri anak dan yang sesuai dengan budaya bangsa Indonesia mencakup nilai-nilai kesopanan, toleransi, kehormatan, kejujuran,bertanggung jawab, bekerjasama, dan beribadah (2014:2)".Penanaman nilai-nilai tersebut perlu mendapatkan perhatian secara khusus di sekolah.Jadi, berdasarkan nilai-nilai yang dikemukakan di atas tampak bahwa penanaman nilai-nilai bagi anak harus dimulai di dalam keluarga dan selanjutnya diteruskan di sekolah lewat pembelajaran.

Pembentukan karakter yang baik diharapkan akan membawa pengaruh positif terhadap prestasi belajar anak. Anak dikatakan berhasil dalam belajar jika memiliki prestasi belajar yang baik dan sesuai dengan target yang diharapkan. Jika anak sudah terbiasa untuk bertanggungjawab terhadap dirinya dan tugas-tugasnya di dalam keluarga maka anak juga akan terbiasa untuk bertanggungjawab terhadap tugas yang diberikan oleh guru. Banyak anak yang memiliki kecerdasan di atas rata-rata tetapi jika anak kurang mendapat perhatian dan dukungan dari keluarga maka sering kali anak tidak mampu mengembangkan potensi yang dimilikinya.Sekolah-sekolah yang berbasis agama khususnya agama Islam dan Budha diharapkan berperan penting dalam upaya pembentukan karakter anak pada tingkat sekolah dasar. Pembentukan karakter itu berhubungan pada nilai-nilai keagamaan sehingga sekolah-sekolah yang berbasis agama diharapkan dapat membawa para peserta didik ke arah perubahan religiusitas yang sejati. Jadi, berdasarkan uraian di atas peneliti tertarik untuk melakukan penelitian tentang : 'Hubungan Pembentukan Karakter di Keluarga dan di Sekolah Dengan Prestasi Belajar Anak di Sekolah Dasar Berbasis Agama Islam dan Budha Sekota Madya Medan'.

\section{Identifikasi Masalah}

Berdasarkan paparan latar belakang masalah yang telah dikemukakan, maka diperoleh beberapa permasalahan yang dapat diidentifikasi sebagai berikut:

1. Pembentukan karakter anak di dalam keluarga masih kurang diperhatikan.

2. Sikap siswa terhadap guru sangat jauh berbeda antara zaman sekarang dengan zaman dulu. 
3. Hubungan pembentukan karakter siswa di keluarga dan di sekolah berbasis agama. Islam dan Budha dapat berpengaruh pada prestasi siswa di sekolah.

\section{Pembatasan Masalah}

Dengan teridentifikasinya permasalahan, maka peneliti membatasi permasalahan penelitian yaitu dengan meneliti Hubungan Pembentukan karakter di keluarga dan di sekolah dengan prestasi belajar anak di sekolah dasar yang berbasis Agama Islam dan Budha Sekotamadya Medan.

\section{Perumusan Masalah}

Berdasarkan latar belakang, identifikasi dan batasan masalah yang disampaikan di atas, maka rumusan permasalahan yang diajukan dalam penelitian ini adalah:

1. Bagaimanakah pembentukan karakter anak di dalam keluarga?

2. Bagaimana pembentukan karakter anak di dalam sekolah yang berbasis agama Islam dan Budha?

3. Apakah ada hubungan yang positif dan signifikan dalam pembentukan karakter di keluarga dan di sekolah yang berbasis agama Islam dan Budha?

\section{Tujuan Penelitian}

Berdasarkan rumusan permasalah yang telah dipaparkan di atas, maka tujuan penelitian ini adalah sebagai berikut:

1. Untuk mengetahui pembentukan karakter anak di dalam keluarga.

2. Untuk mengetahui pembentukan karakter anak di dalam sekolah yang berbasis agama Islam dan Budha.

3. Untuk mengetahui bagaimana hubungan pembentukan karakter siswa di keluarga dan di sekolah berbasis agama Islam dan Budha dapat berpengaruh pada prestasi siswa di sekolah.

\section{Manfaat Penelitian}

Penelitian ini diharapkan dapat memberikan manfaat:

1. Manfaat Teortis

Hasil penelitian dapat memberikan sumbangan yang sangat berharga bagi perkembangan ilmu pendidikan, terutama dalam mengetahui cara pembentukan karakter siswa di sekolah dan rumah.

2. Manfaat Praktis

a. Bagi Peneliti 
Untuk menambah pengetahuan dan informasi tentang hubungan pembentukan karakter di keluarga dan di sekolah dengan prestasi belajar di sekolah SD berbasis agama Islam dan Budha di kota Medan.

b. Bagi Sekolah

Sebagai bahan masukan dan pertimbangan bagi sekolah dasar dalam meningkatkanpembentukan karakter siswa di sekolah .

c. Bagi Guru

Memberi masukan agar guru lebih dapat meningkatkan karakter siswa di sekolah terutama didalam kelas.

d. Bagi Orang tua

Memberi masukan bahwa peranan orang tua dalam pembentukan karakter anak berhubungan dengan prestasi belajar di sekolah.

e. Bagi Siswa

Penelitian ini diharapkan dapat bermanfaat bagi siswa agar siswa lebih meningkatkan karakter yang baik di rumah maupun di sekolah dan siswa juga dapat mengetahui bagaimana perkembangan teknolgi terhadap pembentukan karakter. Sehingga para siswa dapat lebih bijak dalam menggunakan perkembangan teknologi masa sekarang.

\section{METODE PENELITIAN}

\section{Pendekatan Penelitian}

Menurut Arikunto (2010: 13), penelitian merupakan proses mencari tahu tentang kemungkinan penyebab permasalahan antara kondisi nyata dengan kondisi yang diharapkan. Penelitian ini menggunakan penelitian korelasi dengan menggunakan pendekatan kuantitatif karena peneliti bermaksud untuk menggambarkan bagaimana hubungan pembentukan karakter anak di keluarga dan di sekolah dengan prestasi belajar di sekolah dasar berbasis agama Islam dan Budha di kota Medan tahun ajaran $2017 / 2018$. 


\section{Lokasi dan Jadwal Penelitian}

\section{Lokasi Penelitian}

Penelitian dilakukan di sekolah swasta yang berbasis Agama Islam dan Budha di kota Medan.

\section{Jadwal Penelitian}

Penelitian ini dilakukan pada Semester Genap Tahun Pembelajaran 2017/2018, yaitu pada bulan Mei-Juni 2018.

\section{Rancangan/Desain Penelitian}

Desain penelitian yang digunakan pada penelitian ini adalah desain penelitian komparasi kuantitatif. Penelitian kuantitatif digunakan untuk mengetahui hubungan pembentukan karakter di keluarga dan di sekolah terhadap prestasi siswa, sedangkan metode komparasi digunakan untuk menjelaskan pembentukan karakter di keluarga dan disekolah terhadap prestasi belajar siswa di sekolah SD berbasis agama Islam dan Budha.

\section{Populasi dan Teknik Pengambilan Sampel}

\section{Populasi Penelitian}

Menurut Sugiyono (2017:80), populasi adalah wilayah generalisasi yang terdiri atas: obyek/subyek yang mempunyai kualitas dan karakteristik tertentu yang ditetapkan oleh peneliti untuk dipelajari dan kemudian ditarik kesimpulannya. Populasi dalam penelitian ini adalah siswa kelas IV dan VSD dibeberapa sekolah swasta yang berbasis Agama Islam dan Budha Sekotamadya Medan tahun ajaran 2017/2018.

\section{Teknik Pengambilan Sampel}

Menurut Sugiyono (2017: 118), sampel adalah bagian dari jumlah dan karakteristik yang dimiliki oleh populasi. Dengan demikian dapat disimpulkan bahwa sampel adalah bagian dari populasi yang hendak diteliti yang dilihat dari segi jumlah maupun karakteristiknya.

\section{Jenis dan Sumber Data}

\section{Jenis Data}

Menurut Sugiyono (2017: 14), metode penelitian kuantitatif dapat diartikan sebagai metode yang berlandaskan filsafat positivisme, digunakan untuk meneliti pada populasi atau sampel tertentu. Teknik pengambilan sampel dapat digunakan dengan 
menggunakan teknik sampling kuota, menurut Sugiyono (2017:124), sampling kuota adalah teknik untuk menentukan sampel dari populasi yang diinginkan.

\section{Sumber Data}

Arikunto (2013:172) berpendapat bahwa, "sumber data dalam penelitian adalah subjek dari mana data diperoleh".Sumber data dalam penelitian ini berasal dari sekolah tempat peneliti. Sumber data dalam penelitian ini adalah siswa SD kelas IV dan V yang berasal dari sekolah dasar berbasis agama Islam dan Budha Sekotamadya Medan pada tahun ajaran 2017/2018 yang terdiri dari 50\% laki-laki dan 50\% perempuan agar seimbang.

\section{TeknikdanAlatPengumpulan Data}

\section{TeknikPengumpulan Data}

Untuk mendapatkan data dalam penelitian digunakan alat ukur penelitian. Dalam pengumpulan data peneliti memerlukan data,yaitu jenis kelamin, kelas, agama,status sosial sekolah dan ranking siswa. Setiap item pertanyaan dilengkapi dengan lima alternatif jawaban bertingkat yang penskorannya didasarkan pada skala likert yaitu: sangat sering $=5$, sering $=4$, kadang-kadang $=3$, jarang $=2$ dan tidak pernah $=1$. Langkah-langkah pengumpulan data sebagai berikut:

1. Observasi

2. Wawancara

3. Angket

4. Studi dokumentasi

\section{Alat Pengumpulan Data}

Sugiyono (2017: 199) mengemukakan, alat pengumpulan data yang dilakukan peneliti dalam penelitian ini yaitu, kuesioner (angket). Kuesioner merupakan teknik pengumpulan data yang dilakukan dengan cara memberi seperangkat pertanyaan atau pernyataan tertulis kepada responden untuk dijawabnya. Kuesioner merupakan teknik pengumpulan data yang efesien bila peneliti tahu dengan pasti variabel yang akan diukur dan tahu apa yang bisa diharapkan dari responden.

\section{Validitas dan Reliabilitas Instrumen}

Menurut Sugiyono (2010: 121) instrumen yang valid berarti alat ukur yang digunakan untuk mendapatkan data (mengukur) itu valid. Instrumen yang reliabel adalah instrumen yang bila digunakan beberapa kali untuk mengukur obyek yang sama, akan menghasilkan data yang sama. 


\section{Teknik Pengolahan (Analisis) Data}

Teknik pengolahan data menggunakan korelasi berganda. Menurut Sugiyono (2016: 231) korelasi berganda (multiple correlation) merupakan angka yang menunjukkan arah dan kuatnya hubungan antara dua variabel independen secara bersama-sama atau lebih dengan satu variabel dependen.

Penelitian ini dilakukan dengan bantuan program SPSSversi 22for windows. Untuk melihat hubungan dua variabel dalam penelitian ini, yang dilakukan oleh peneliti adalah:

1. Memasukkan data dari sekolah Islam dan Budha ke dalam SPSS ver. 22 for windows.

2. Alternatif jawaban angket yang terdiri dari 5 pilihan, direcord menjadi tiga alternatif, yaitu: 1). Tidak pernah, 2). Jarang, 3). Sering.

3. Mencari korelasi antara dua variabel.

Adapun ketentuan korelasi (r) antara dua variabel dalam penelitian ini menurut Julie Pallat (2007; 132) adalah sebagai berikut:

1. $0=$ tidak ada korelasi antara dua variabel.

2. $>0-0,25=$ korelasi sangat lemah.

3. $>0,25-0,5=$ korelasi cukup.

4. $>0,5-0,75=$ korelasi kuat.

5. $>0,75-0,99=$ korelasi sangat kuat.

6. 1 = korelasi sempurna.

Sedangkan kriteria dari signifikannya (p) adalah:

1. 0,01 berarti tingkat kepercayaannya dalam riset sebesar 99 persen,

2. 0,05 berarti tingkat kepercayaanya dalam riset sebesar 95 persen,

3. 0,1 berarti tingkat kepercayaanya sebesar 90 persen.

\section{Prosedur Penelitian}

Menurut John Creswell (2015: 285), langkah-langkah dalam proses pengumpulan data kuantitatif:

1. Menentukan partisipan dalam penelitian,

2. Mendapatkan izin yang yang dibutuhkan dari beberapa individudan organisasi

3. Mempertimbangkan tipe informasi yang dikumpulkan dari beberapa sumber yang tersedia untuk penelitian 
4. Melokalisasi dan menyeleksi instrumen yang akan digunakan untuk menagkap data yang bermanfaat untuk penelitian

5. Mengadministrasikan proses pengumpulan data untuk menghimpun data.

\section{HASIL PENELITIAN DAN PEMBAHASAN}

\section{Pembahasan Hasil Temuan}

Seperti yang sudah dirumuskan dalam Bab 1, penelitian ini fokus pada pertanyaan-pertanyaan sebagai berikut:

4. Bagaimanakah pembentukan karakter anak di dalam keluarga?

5. Bagaimana pembentukan karakter anak di dalam sekolah yang berbasis agama Islam dan Budha?

6. Apakah ada hubungan yang positif dan signifikan dalam pembentukan karakter di keluarga dan di sekolah yang berbasis agama Islam dan Budha?

Berikut ini akan diuraikan satu persatu pertanyaan-pertanyaan penelitian tersebut berdasarkan hasil analisa data penelitian:

\section{a. Bagaimana pembentukan karakter anak di dalam keluarga?}

Keluarga merupakan faktor primer dalam membentuk kepribadian anak, cara orangtua dalam memberi perhatian, penghargaan dan pengajaran akan memberikan kesan yang mendalam bagi perasaan, pemikiran, sikap, dan tingkah laku anak ketika anak mulai beranjak dewasa. Pembentukan karakter dalam keluarga dapat dilakukan melalui pendidikan nilai hidup yang sesuai dengan ajaran agama, masyarakat, bangsa dan negara. Perkembangan anak juga akan sangat terbantu jika orangtua dapat menjadi teladan yang baik untuk anak-anaknya.

Berdasarkan data penyebaran yang telah dibagikan maka diperoleh bahwa pembentukan karakter yang di lakukan di keluarga adalah: 1). Aspek religius; orangtua mengajak anak berdoa, orangtua mengajak anak pergi ke rumah ibadah, orangtua mengajak anak membaca kitab suci, orangtua mengajari anak hidup rukun dengan agama lain, dan mengajari perbuatan dosa dan tidak berdosa. Dari aspek religius, hal yang paling banyak dilakukan oleh keluarga Islam dan Budha adalah "orangtua sering mengajak anak berdoa". Itu artinya orangtua selalu memberikan perhatian kepada anak dengan cara mengajak anak berdoa sehingga anak merasa termotivasi dan semakin semangat dalam melakukan setiap kegiatan karena adanya perhatian dan motivasi dari 
orangtua. Perhatian dan motivasi merupakan salah satu faktor dalam keberhasilan belajar anak, itu sebabnya pada aspek religius "orangtua sering mengajak anak berdoa" memiliki hubungan yang paling besar dalam meningkatkan prestasi belajar anak dan membentuk karakter anak.

2). Aspek kejujuran; orangtua memuji anak ketika berkata jujur, orangtua menghukum anak ketika berkata tidak jujur, orangtua mengajari anak berterus terang pada orangtua, anak mendengar orangtua berbohong dan orangtua memberitahu anak bahwa Tuhan tidak suka dengan ketidak jujuran. Pada aspek kejujuran hal yang paling sering dilakukan adalah "orangtua sering memberitahu anak bahwa Tuhan tidak suka dengan ketidak jujuran" hal ini menunjukkan bahwa dengan ditanamkannya nilai kejujuran di dalam diri anak akan dapat mempengaruhi nilai prestasi anak karena kejujuran itu merupakan suatu faktor yang dapat menunjang keberhasilan belajar anak. Jika orangtua sering menanamkan sifat jujur atau karakter yang baik dalam diri anak di rumah, maka sifat jujur tersebut akan terbawa-bawa di sekolah dan akan mempengaruhi prestasi belajarnya, dengan demikian anak akan menghindari yang namanya mencontek dan pelanggaran-pelanggaran lainnya yang dapat mengurangi nilainya di sekolah.

3). Aspek disiplin; orangtua mengajari anak datang ketika dipanggil, orangtua memberikan tugas membersihkan kamar, menyuruh anak tidak pada waktunya, orangtua menyuruh anak untuk tidur pada waktunya, orangtua menghukum anak ketika tidak disiplin dan dan orangtua memberitahu peraturan-peraturan di rumah. Dalam hal ini, point yang paling sering di lakukan oleh orangtua adalah orangtua sering memberitahu peraturan-peraturan di rumah. Dengan memberitahu peraturan-peraturan di rumah, karakter anak akan dibentuk menjadi lebih baik dan disiplin. Biasanya salah satu peraturan di rumah itu adalah membagi jam belajar dan jam bermain anak. Dengan demikian anak akan semakin tertib dalam hal belajar dan dapat menunjang keberhasilan belajarnya sehingga dapat meningkatkan prestasinya di sekolah.

4). Aspek kepedulian sosial; orangtua mengajari anak untuk menghargai teman, orangtua mengajari anak untuk berani meminta maaf jika melakukan kesalahan, orangtua mengajari anak membantu orang yang membutuhkan, orangtua mengajari anak untuk tidak berlaku kasar dan orangtua mengajari anak untuk menghargai orang lain. Dan pada aspek ini, hal yang paling sering dilakukan adalah "orangtua sering mengajari anak untuk menghargai oranglain" dengan mengajari anak untuk menghargai 
orang lain, anak bisa tumbuh menjadi karakter yang lebih peduli dan memiliki rasa simpati terhadap orang-orang di sekitarnya.

5). Aspek tanggung jawab; orangtua memberikan tugas untuk diselesaikan, orangtua memberikan kesempatan untuk mengambil keputusan sendiri, orangtua memberikan kesempatan lain ketika melakukan kesalahan, orangtua memberikan kepercayaan kepada anak dan orangtua memberikan contoh tanggung jawab. Pada aspek ini, "orangtua memberikan kesempatan untuk mengambil keputusan sendiri" merupakan hal yang paling banyak dilakukan oleh orangtua. Itu tandanya dengan memberikan kepercayaan kepada anak, bisa membuat anak tumbuh menjadi pribadi yang bertanggung jawab terhadap tugas yang dia miliki dan dapat membuat anak tersebut semakin semangat juga termotivasi dalam segala hal termasuk dalam kegiatan sekolahnya sehingga dapat menunjang proses belajarnya di rumah maupun di sekolah.

Jadi dapat disimpulkan bahwa, orangtua di keluarga Islam dan orangtua di kelurga Budha harus lebih memperhatikan perkembangan karakter anak di dalam lingkungan rumah, karena bagaimana pun awal mula pembentukan karakter anak itu berasal dari rumah atau lingkungan keluarganya. Jika anak itu dididik dengan baik dan selalu diberikan motivasi juga dorongan, maka karakter anak tersebut akan menjadi baik dan akan semakin semangat dalam melakukan kegiatannya sehari-hari temasuk kegiatan belajarnya di rumah dan di sekolah.

\section{b. Bagaimana pembentukan karakter anak di dalam sekolah yang berbasis agama Islam dan Budha?}

Setelah anak memperoleh pendidikan di keluarga, anak akan memperoleh pendidikan di sekolah. Pendidikan di sekolah juga tidak hanya tentang ilmu pengetahuan tetapi juga tentang penanaman moral, etika, agama dan sebagainya. Dalam pengajaran ini, terlebih dahulu guru harus menjadi contoh karakter yang baik kepada siswa di sekolah.

Dari hasil jawaban respondenmengatakan bahwa pembentukan karakter yang di lakukan di sekolah adalah: 1). Aspek religius; guru sering mengingatkan anak untuk rajin pergi ke rumah ibadah, guru mengajak anak berdoa sebelum dan sesudah belajar, guru mengajari sikap yang baik dalam berdoa, guru mengajari hidup rukun dengan agama lain, dan guru mengajari tentang perbuatan dosa dan tidak berdosa. Dari aspek religius yang paling sering dilakukan adalah "guru mengingatkan untuk rajin pergi ke 
rumah ibadah", hal ini merupakan salah satu bentuk perhatian guru terhadap anak agar anak selalu mengingat untuk pergi ke rumah ibadah. Perhatian merupakan salah satu faktor yang dapat membentuk karakter anak dan dapat meningkatkan semangat anak dalam melakukan kegiatannya termasuk kegiatan belajar. Maka dari itu dengan adanya perhatian dari guru, prestasi belajar anak bisa semakin meningkat.

2). Aspek kejujuran; guru mengingatkan anak untuk tidak mencontek saat ujian, guru menghukum anak ketika anak ketahuan mencontek, guru berbohong, guru memuji anak ketika berkata jujur dan guru memberitahu bahwa Tuhan tidak suka dengan ketidak jujuran. Pada aspek ini hal yang paling sering dilakukan oleh guru adalah "guru sering mengingatkan anak untuk tidak mencontek saat ujian”. Hubungan prestasi belajar anak dengan tidak mencontek saat ujian adalah ketika anak tidak mencontek itu artinya anak diharuskan untuk memahami pelajaran tersebut sehingga anak bisa mengerjakan setiap soal ujian dengan baik. Dengan demikian jika anak sudah memahami setiap pelajaran yang diberikan otomatis nilai anak akan bagus dan akan semakin meningkat.

3). Aspek disiplin; guru mengingatkan anak untuk datang tepat waktu, guru memberitahu peraturan-peraturan di sekolah, guru mengurangi nilai jika terlambat mengumpulkan tugas, guru menghukum anak ketika anak tidak disiplin dan anak mengumpulkan tugas tepat waktu. Dalam aspek ini hal yang paling sering dilakukan oleh guru adalah "guru mengingatkan untuk datang tepat waktu". Di sekolah pengetahuan bukanlah faktor utama anak disebut berprestasi tetapi ahlak atau sikap juga merupakan faktor penentu anak agar bisa dikatakan berprestasi.

4). Aspek kepedulian sosial: guru mengajari untuk menghargai teman, guru mengajari anak untuk meminta maaf ketika melakukan kesalahan, guru mengingatkan anak untuk selalu bekerjasama dalam kelompok, guru mengingatkan anak untuk tidak membeda-bedakan teman dan guru mengajari anak untuk membantu orang yang membutuhkan. Pada aspek ini hal yang paling sering dilakukan adalah "guru sering mengajari untuk berani meminta maaf jika melakukan kesalahan. Pada paragraf sebelumnya dikatakan bahwa pendidikan di sekolah tidak hanya tentang ilmu pengetahuan tetapi juga tentang penanaman moral, etika, agama dan sebagainya. Berani meminta maaf itu merupakan salah satu pembentukan karakter mengenai etika. Dalam penilaian di sekolah bukan hanya pengetahuan saja tetapi juga mengenai karakter anak. Itu sebabnya, karakter anak yang kurang baik dapat mempengaruhi prestasi anak di sekolah. 
5). Aspek tanggung jawab; guru memberikan PR, guru menghukum anak ketika tidak mengerjakan tugas, guru membagi tugas piket di kelas, guru meminta bantuan siswa untuk melakukan sesuatu, dan guru memberi kesempatan lain ketika anak melakukan kesalahan. Pembentukan karakter di sekolah yang paling banyak dilakukan adalah "guru sering memberikan PR". Dalam hal ini selain pemahaman anak semakin meningkat soal pelajaran, tanggung jawab anak juga akan semakin terlatih dan semakin baik. Anak di tuntut untuk dapat menyelesaikan tugas dengan baik dan tepat waktu, itu artinya anak harus mengerjakan PR tersebut dengan benar dan dikumpulkan pada waktu yang sudah ditentukan oleh guru.

Jadi kesimpulannya, diharapkan guru-guru di sekolah dapat lebih bijak dan fokus dalam membentuk karakter agar tumbuh menjadi anak yang memiliki karakter yang baik juga memiliki ilmu pengetahuan yang baik pula.

\section{c. Apakah ada hubungan yang positif dan signifikan dalam pembentukan karakter di keluarga dan di sekolah yang berbasis agama Islam dan Budha.}

Seperti yang sudah dijelaskan pada tabel korelasi dan signifikan, pembentukan karakter di keluarga dan di sekolah mempunyai relasi atau hubungan dengan prestasi belajar anak. Seperti pada aspek religius di keluarga Budha "orangtua mengajak anak berdoa" merupakan hubungan paling besar antara pembentukan karakter anak dengan prestasi belajar anak. Kemudian pembentukan karakter anak di keluarga Budha dengan “mengajak anak pergi ke rumah ibadah" juga memiliki hubungan yang positif dan signifikan terhadap prestasi belajar anak. Kemudian pada aspek kejujuran di keluarga Budha "orangtua menghukum anak ketika tidak jujur" memiliki hubungan yang sangat besar antara pembentukan karakter anak di rumah dengan prestasi belajar anak. Selanjutnya pada aspek kejujuran di keluarga Budha "orangtua menghukum anak ketika tidak jujur" merupakan pengaruh terbesar dalam pembentukan karakter anak dan dapat mempengaruhi nilai anak di sekolah. Dalam "anak mendengar orangtuanya berbohong” di keluarga Budha ternyata dapat mempengaruhi pembentukan karakter anak dan prestasi belajar anak, ini dibuktikan dengan adanya korelasi dan hubungan yang positif antara pembentukan karakter anak dengan hasil belajar anak. Pada aspek disiplin di keluarga Budha "orangtua memberi tugas membersihkan kamar, mencuci piring, dll" mendapatkan posisi paling tinggi dari antara poin yang ada pada aspek disiplin. Hal ini membuktikan bahwa adanya hubungan yang positif terhadap pembentukan karakter 
dengan prestasi belajar anak. Dilanjutkan dengan "orangtua menghukum ketika anak tidak disiplin" di keluarga Budha ternyata memiliki korelasi dan signifikan terhadap prestasi anak dan pembentukan karakter anak. Kemudian pada aspek kepedulian sosial “orangtua mengajari anak untuk berani meminta maaf ketika melakukan kesalahan" di keluarga Budha mengatakan bahwa pembentukan karakter pada poin tersebut menjadi pengaruh paling tinggi terhadap prestasi belajar anak. Disusul oleh "orangtua mengingatkan anak untuk selalu menghargai orang lain" di keluarga Budha ternyata juga memiliki hubungan yang positif dan signifikan antara pembentukan karakter dengan prestasi belajar anak. Yang terakhir adalah aspek tanggung jawab yaitu “orangtua memberikan tugas untuk diselesaikan” di keluarga Budha merupakan aspek yang paling tinggi yang dapat mempengaruhi pembentukan karakter anak dan memberikan pengaruh dalam menigkatkan hasil belajar anak. Selanjutnya pada aspek tanggung jawab "orangtua memberikan kesempatan lain ketika anak melakukan kesalahan" di keluarga Budha juga memberikan dampak yang positif dalam meningkatkan prestasi anak dan dapat membentuk karakter anak menajadi lebih baik lagi.

Sedangkan pada aspek religius di sekolah Budha "guru mengajari hidup rukun dengan agama lain" merupakan hal paling besar dalam membentuk karakter anak dan memberikan nilai positif terhadap hasil belajar anak. Selanjutnya "guru mengajari hidup rukun dengan agama lain" di sekolah Budha juga ternyata dapat mempengaruhi pembentukan karakter anak dan prestasi belajar anak. Pada aspek kejujuran "“"guru berbohong" di sekolah Islam memiliki hubungan yang positif terhadap hasil belajar anak. Pada aspek disiplin "guru mengingatkan untuk datang tepat waktu" ternyata dapat memberikan pengaruh yang positif terhadap prestasi anak, terbukti dengan adanya nilai yang signifikan dan adanya korelasi pada tabel sebelumnya. Kemudian pada aspek kepedulian sosial di keluarga Budha "guru mengingatkan untuk selalu bekerjasama dalam kelompok" mengalami penurunan nilai dari prestasi sekarang dengan prestasi sebelumnya walau demikian aspek tersebut memiliki hubungan yang positif terhadap pembentukan karakter anak dan dapat mempengaruhi nilai anak di sekolah. Dan terakhir pada aspek tanggung jawab "guru memberikan kesempatan lain ketika anak melakukan kesalahan" di keluarga Budha ternyata memiliki nilai paling tinggi dalam aspek tanggung jawab. Hal ini menandakan bahwa poin"guru memberikan kesempatan 
lain ketika anak melakukan kesalahan" di sekolah Budha memberikan pengaruh yang positif dalam pembentukan karakter anak dan dapat meningkatkan hasil belajar anak.

Jadi, berdasarkan hasil perhitungan dari jawaban responden tentang kelima aspek tersebut yaitu, aspek religius, aspek kejujuran, aspek disiplin, aspek kepedulian sosial dan aspek tanggung jawab dapat membuktikan bahwa pembentukan karakter anak di keluarga dan di sekolah memiliki pengaruh dalam meningkatkan prestasi belajar anak.

\section{PENUTUP}

\section{Simpulan}

Berdasarkan uraian yang telah dikemukakan pada bab sebelumnya, maka dapat dikemukakan beberapa simpulan dari penelitian yaitu:

1. Pembentukan karakter anak di keluarga Islam dan Budha dipengaruhi oleh lima aspek, pembentukan karakter di keluarga dan di sekolah mempunyai relasi atau hubungan dengan prestasi belajar anak seperti yang sudah dijelaskan pada pertanyaan hasil temuan sebelumnya. Seperti pada aspek religius di keluarga Budha “orangtua mengajak anak berdoa, aspek kejujuran di keluarga Budha "orangtua menghukum anak ketika tidak jujur”, pada aspek disiplin di keluarga Budha “orangtua memberi tugas membersihkan kamar, mencuci piring, aspek kepedulian sosial "orangtua mengajari anak untuk berani meminta maaf ketika melakukan kesalahan" dan pada aspek tanggung jawab "orangtua memberikan kesempatan lain ketika anak melakukan kesalahan" memiliki pengaruh positif terhadap pembentukan karakter anak dan dapat mempengaruhi hasil belajar anak.

2. Berdasarkan hasil analisa terhadap kelima aspek tersebut, yaitu aspek religius, aspek kejujuran, aspek disiplin, aspek kepedulian sosial dan aspek tanggung jawab diperoleh hasil yang mengatakan bahwa kelima aspek tersebut memiliki pengaruh dalam pembentukan karakter anak dan meningkatkan prestasi belajar anak di sekolah.

3. Berdasarkan hasil perhitungan dari jawaban responden tentang hal-hal yang dilakukan dalam pembentukan karakter di keluarga dan di sekolah maka diperoleh hasil yang menyatakan bahwa pembentukan karakter di keluarga dan di sekolah ada memiliki hubungan yang positif dan signifikan dalam pembentukan karakter di 
keluarga dan di sekolah yang berbasis agama Islam dan Budha Sekota Madya Medan.

\section{Saran}

Berdasarkan simpulan, implikasi, dan keterbatasan penelitian yang sudah dipaparkan, maka dapat diberikan saran-saran sebagai berikut:

1. Meskipun pembentukan karakter di keluarga dan di sekolah tidak memiliki pengaruh yang besar terhadap prestasi belajar, alangkah baiknya jika orangtua dan guru tetap mengajarkan karakter yang baik kepada anak.

2. Pembentukan karakter yang memiliki pengaruh terhadap prestasi belajar dari hasil penelitian ini dapat dikembangkan oleh keluarga maupun sekolah.

\section{DAFTAR PUSTAKA}

Suyanto. 2010. Pendidikan Karaker Teori dan Aplikasi. Jakarta: Rineka Cipta.

Pallat, Julie 2007. Survival Manual. New York: Markono

Damayanti, Deni. 2014. Panduan Implementasi Pendidikan Karakter Di Sekolah. Yokyakarta: Araska.

Arikunto, Suharsimi. 2010. Dasar-Dasar Evaluasi Pendidikan. Jakarta : Bumi Aksara.

Sugiyono. 2017. Metode Penelitian Pendidikan Kuantitatif, Kualitatif, dan R\&D. Bandung: Alfabeta.

. 2010. Metode Penelitian Pendidikan Kuantitatif, Kualitatif, dan R\&D. Bandung: Alfabeta.

2016. Statistika Untuk Penelitian. Bandung: Alfabeta

Creswell, John. 2015. Riset Pendidikan Perencanaan, Pelaksanaan, dan Evaluasi, Riset Kuantitatif \& Kualitatif. Yokyakarta: Pustaka Belajar.

Sudaryanti. 2012. Pentingnya Pendidikan Karakter Bagi Anak Usia Dini. Vol.1. Diakses dari http:/ /journal.uny.ac.id/index tanggal 15 Januari 2018.

Rantauwati, Sri, Henny. 2014. Pengembangan Karakter Siswa SD Melalui Bermain Peran. No. 01/Tahun XVIII/Mei. 2014.Diakses dari http:/ /journal.uny.ac.id/index tanggal 15 Januari 2018.

Maunah, Binti. 2015. Implementasi Pendidikan Karakter Dalam Pembentukan Kepribadian Holistik Siswa. Tahun V, No. 1. April. 2015. Diakses dari http:/ /journal.uny.ac.id/index tanggal 15 Januari 2018. 
Nasehudin. 2015. Pembentukan Sikap Sosial Melalui Komunikasi Dalam Keluarga. Vol. IV. NO. 1. Januari-Juni. 2015. Diakses dari http:/ /journal.uny.ac.id/index tanggal 15 Januari 2018.

Sianipar, Godlif dan Nainggolan, Candra, Arisan. 2017. Implementasi Pendidikan Nilai Oleh Guru Sekolah Berbasis Agama. Medan

https://regional.kompas.com/read/2018/02/03/10041991/penganiayaan-guru-oleh-siswadi-sampang-begini-kronologinya. [Diakses 17 April 2018]

http://kaltim.tribunnews.com/2016/10/21/video-parah-bocah-sd-berani-lawan-gurunyabilang-monyet-pula. [Diakses 17 April 2018]

https://regional.kompas.com/read/2018/03/08/12274191/ditegur-karena-main-ponsel-dikelas-murid-hajar-guru-dengan-kursi. [Diakses 17 April 2018] 